\title{
The impact of global purchasing and supplier integration on product innovation
}

\author{
Robin von Haartman and Lars Bengtsson \\ University of Gävle, Gävle, Sweden
}

Global purchasing and supplier integration

Received 30 September 2013

Revised 26 May 2014

31 August 2014

Abstract

Purpose - The interest in global purchasing has increased significantly in recent years, but the impact on product innovation is not well understood. The purpose of this paper is to empirically analyse the impact of global purchasing on product innovation sourced from suppliers, while taking into account how firms integrate their suppliers.

Design/methodology/approach - The data used in this study are from the International Purchasing Survey, an international online survey on purchasing and supply management conducted in 2009. The data are analysed using factor and regression analyses.

Findings - The paper shows that global purchasing has no direct impact on product innovation performance. However, supplier integration is more strongly associated with product innovation performance for firms purchasing globally compared to firms purchasing regionally.

Practical implications - The implication is that when companies purchase globally, they must have a highly developed purchasing department in order to sustain a high level of innovation. For firms purchasing only regionally, the role of the purchasing department is diminished, at least in terms of contributing to innovation.

Originality/value - This paper contributes to the discussion of potential advantages and disadvantages of global purchasing. First, the paper provides an explanation for the ambiguous results of previous research. Product innovation does not depend on whether firms are purchasing globally or not, it depends on how they purchase. This paper has showed that when purchasing globally, the role of the purchasing department becomes crucial for product innovation. The proficiency and activities of the purchasing department largely determine the success, in terms of supplier product innovation, of global purchasing.

Keywords Innovation, Survey, Supply chain management, Globalization, Purchasing,

Global operations management

Paper type Research paper

\section{Introduction}

The interest in global purchasing and offshore outsourcing has increased significantly in recent years. This has initially been driven by expectations of cost reduction (Trent and Monczka, 2003; Holweg et al., 2011) when goods and services are purchased from low-cost regions. An increasingly important rationale concerns a desire to acquire knowledge and technology from external suppliers (Henke and Zhang, 2010; Lau et al., 2010). Accordingly, development of advanced technological products has increasingly become an interorganisational process, involving webs of geographically dispersed players and manufacturing sites (Contractor et al., 2010; Brusoni et al., 2001;

(C) Robin von Haartman and Lars Bengtsson. Published by Emerald Group Publishing Limited. This article is published under the Creative Commons Attribution (CC BY 3.0) licence. Anyone may reproduce, distribute, translate and create derivative works of this article (for both commercial \& non-commercial purposes), subject to full attribution to the original publication and authors. The full terms of this licence may be seen at http://creativecommons.org/licences/by/3.0/legalcode. The support of VINNOVA (Sweden's innovation agency) is gratefully acknowledged.

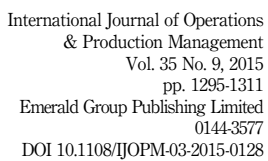


IJOPM

35,9

1296

Chiesa et al., 2000). This new approach to product development becomes all the more challenging the more geographically distant the suppliers are (Narasimhan and Nair, 2005). Facilitating such development necessitates both advanced supplier integration tools and a proficient purchasing department (see e.g. Kauppi et al., 2013).

Despite these arguments, it is less known how global purchasing actually impacts performance. Studies on international and global purchasing have apparently been more interested in questions regarding what to buy and from where (see e.g. the overview in Karjalainen and Salmi, 2013), rather than what the effects are. There are rather few broader empirical studies measuring the actual outcome of global purchasing, and even fewer that have been able to show a positive relationship to company performance (see Kotabe et al., 2008; Quintens et al., 2006; Mol et al., 2005). When comparing two cases, Steinle and Schiele (2008) typically concluded that a "high global sourcing quota does not necessarily improve a firm's competitiveness". The studies on cost effects of global purchasing show mostly ambiguous results or fail to show any effects (see Chiang et al., 2012; and an overview in Schiele et al., 2011).

Corresponding large-scale studies on the impact of global purchasing on product innovation performance are even rarer. This link may represent a complex pattern. While global purchasing may indeed open doors to external knowledge, some studies question its effects on product innovation. Distant purchasing may cause extended lead times that have a negative effect on time-to-market (TTM) in new product development (NPD) (Allocca and Kessler, 2006; Bengtsson and Berggren, 2008). Studies of product development further argue for the need to co-locate and integrate key activities, processes and knowledge in product and manufacturing processes, specifically in development of complex products (e.g. Ulrich and Ellison, 2005; Liu et al., 2013). The product innovation outcome of global purchasing is thus interesting to analyse further. While previous studies have illuminated the role of supplier integration in global product development (e.g. Kleinschmidt et al., 2007), this study focuses explicitly on the product innovation outcome when purchasing globally.

The overall purpose of this paper is to empirically analyse the impact of global purchasing on innovation sourced from suppliers, while taking into account how firms integrate their suppliers. More specifically, the study tests four sets of hypotheses, where the first two concern the difference between firms purchasing globally and those that do not, in terms of both innovation-related priorities for purchasing and supplier product innovation. The latter two sets of hypotheses concern the impact of supplier integration on supplier product innovation, and whether this impact differs between firms purchasing globally and those that do not.

The paper is based on a large-scale survey of purchasing managers in 679 firms in Europe and North America. Many surveys tend to focus on the firm level and thus miss the fact that different component categories are, or should be, sourced using different strategies, as was pointed out by Kraljic (1983). Therefore, this survey focused on the component category level. The next section of the paper will review the relevant literature and formulate hypotheses. The following sections outline the methodology, results, discussion and finally conclusions.

\section{Global purchasing - concepts and hypotheses}

There is no clear definition of the term global purchasing in the literature (Quintens et al., 2006). The term is instead intimately related to and intermittently used together with terms such as international or multinational sourcing, offshore sourcing or outsourcing (Trent and Monczka, 2003; Mol et al., 2005; Kotabe et al., 2008). Generally, 
global sourcing is a broader concept than international purchasing and is concerned with coordinating materials flow, processes, designs, technologies and suppliers across a company's global locations (Trent and Monczka, 2003). We adopt the term global purchasing and base it on the definition of Quintens et al. (2006): "The activity of searching and obtaining goods, services and other resources on a possible worldwide scale [...]", which also includes integrating and developing the supplier base.

Mol et al. (2004) showed that scope (the fact that the company purchases globally) has more impact on innovation than scale (the percentage of goods or services purchased outside the home country). The reason may be that innovative firms may need to search for key components globally, while still purchasing most items locally (Quintens et al., 2006). Mol et al. (2005) and Karjalainen and Salmi (2013) differentiate among three types of purchasing based on the different challenges and transaction costs that trade zones create: domestic purchasing, regional purchasing and global purchasing. While our focus is on the global impact, we distinguish between global purchasing, i.e., purchasing a significant quantity of the selected component category outside the firm's home continent and regional purchasing, i.e., within the firm's home continent.

\section{Priorities and outcomes}

To shed further light on the issue of why companies purchase globally, we first analyse innovation-related motives. One motive concerns the ambition to acquire cutting-edge knowledge, competencies and technology from suppliers located all over the world (Kotabe et al., 2008; Mol et al., 2004). A related motive for global purchasing stems from the fact that some specialised components and technical expertise are only available in certain locations (Kotabe et al., 2008; Mol et al., 2004). This means that truly innovative companies struggle to find local suppliers that conform to the requirements for the innovative content of their components (Murray, 2001). These two motives reflect the ambition to become more innovative and can also be seen as a company's wish to gain access to assets or resources that are unique to some extent. The motives also explain why the development of advanced technological products has become a global and interorganisational process that involves a number of geographically dispersed firms and suppliers (Contractor et al., 2010; Brusoni et al., 2001). Indeed, technological and innovation factors have been identified as the most important drivers for global purchasing (Mol et al., 2004).

Although many authors have researched the concept of global purchasing, few have investigated its relation to innovation performance. Several studies of global purchasing have analysed the effects on product delivery. For example, Golini and Kalchschmidt (2011) report that although global purchasing generally has a negative impact on inventory, the adoption of supplier integration can reduce that effect. Another rather common theme in the study of global purchasing is the trade-off between costs and delivery flexibility or agility (Chiang et al., 2012). Holweg et al. (2011) developed a model of risk and the negative effects of global purchasing, but their model does not include the direct effects on innovation. As an indirect effect, they include the potential loss of intellectual property rights. In purchasing, appropriate measures of supplier product innovation performance are the time taken to bring a product/service to market (or TTM) and the level of innovation in products/services from suppliers (Monczka et al., 2005). Research has also found a trade-off between the level of product innovation and TTM (Karlsson and Åhlström, 1999).

Since global purchasing opens up access to cutting-edge competencies and technologies, it is reasonable to expect it to improve innovation performance, in terms 
IJOPM

35,9

1298

of the level of product innovation provided by suppliers (see e.g. Lau et al., 2010). Product standardisation and the increased use of IT, including common tools such as e-mail, web-based meetings or ERP systems, are also likely to reduce the need for geographically close suppliers (Durmoşoğlu and Barczak, 2011; Demeter, 2013; Olson et al., 2013). On the other hand, we know from studies on advanced product development that the innovation and knowledge integration processes are characterised by fuzzy interfaces between different technologies and competencies, a complexity that mandates proximity, co-location and integration of key activities (Ulrich and Ellison, 2005). Other factors that can lead to an increased need for geographical proximity are concurrent engineering, a high degree of customisation and an emphasis on knowledge sharing (Demeter, 2013). Global purchasing could thus be expected to slow the innovation process and thereby prolong TTM. Since most firms likely know this, they are likely to put more effort into trying to reduce TTM if they have a global supplier base. We thus extract the following hypotheses (see also Figure 1):

H1a. Firms purchasing globally prioritise a higher introduction rate of new products than firms that do not purchase globally.

H1b. Firms purchasing globally prioritise improving TTM for new products to a greater extent than firms that do not purchase globally.

H2a. Firms purchasing globally experience a higher level of supplier product innovation, compared to firms that purchase globally.

$H 2 b$. Firms purchasing regionally experience a shorter TTM by their suppliers, compared to firms that do not purchase globally.

\section{Supplier integration - tools and proficiency}

A basic driver for global purchasing and outsourcing is the ambition to extend the firms' organisational and technological capability by coordinating networks of suppliers (Mudambi, 2008). This suggests that global purchasing may have no clear and straightforward impact on product innovation. Rather, how the firm is able to build up the ability to exploit potential capabilities in the networks determines the outcome. This ability can be referred to as supply chain integration and is defined as "the degree to which a manufacturer strategically collaborates with its supply chain partners and collaboratively manages intra- and inter-organization processes" (Flynn et al., 2010).

Since this paper deals with purchasing, we will focus only on the integration of suppliers in intra- and interorganisational processes. That integrating suppliers in

Figure 1.

Conceptual model, $H 1$ and $H 2$

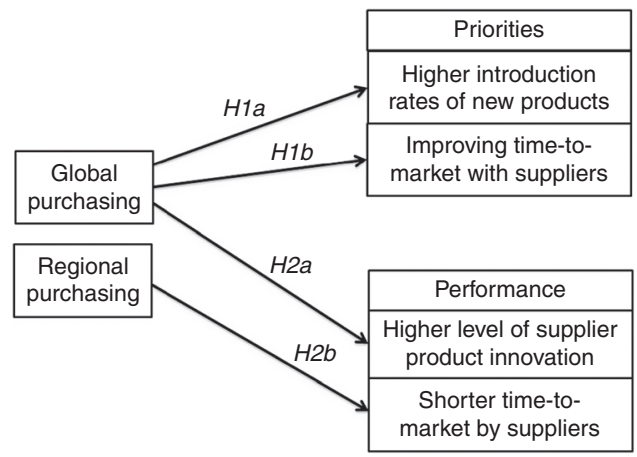


company processes will have an impact on performance is nothing new. Already back in 1983, Kraljic advised firms to form strategic partnerships with suppliers if the supply market is highly concentrated and the impact of the purchased components is high. In fact, many supply chain articles (e.g. Fawcett et al., 2010) advise firms to integrate their suppliers in order to improve performance, including innovation. Many recent studies have also found that the integration of suppliers is indeed associated with better innovation performance (e.g. Lau et al., 2010; Schiele, 2010).

When suppliers are located geographically close to their customers, communication becomes easier (Narasimhan and Nair, 2005). To get the same innovation benefits from distant suppliers, a larger degree of formal supplier integration may thus be needed (Kleinschmidt et al., 2007). Previous studies have found it advantageous for companies that prioritise delivery speed and reliability to choose local suppliers, although supplier integration can compensate for some of the negative effects of distance (Demeter, 2013). Other studies have also found that supplier integration is required for harnessing the innovation potential of new suppliers when outsourcing manufacturing (Bengtsson et al., 2009). Perols et al. (2013) found that supplier integration in NPD is effective for improvements in TTM. Other studies have found that logistics-related integration has an impact on company performance, including product innovation (Flynn et al., 2010; Prajogo and Olhager, 2012).

A stream of literature focuses only on the innovation effects of geographic proximity. For example, Liu et al. (2013) report that although globalisation has increased the geographical spread of innovation networks, local networks continue to be critical for innovation, because some knowledge is easier to extract in geographically close networks. Although geographical proximity is generally considered to be beneficial for innovation, some studies question whether the positive innovation effects are due to geographical proximity alone (Huber, 2012). Yet the studies of geographical distance and its effect on innovation generally do not have a purchasing perspective, meaning that they do not take into account supplier integration or proficiency. This is surprising, considering that Kleinschmidt et al. (2007) found that supplier integration has a bigger effect on the success of global NPD projects than any other NPD process capabilities.

The purchasing function is at the core of implementing the business strategy and managing integration needs related to global purchasing (Kauppi et al., 2013). Several studies have indeed shown that high skills in purchasing lead to superior performance in many areas, including innovation (Gonzalez-Benito, 2007; Luzzini and Ronchi, 2011), but the empirical evidence is surprisingly weak (Saranga and Moser, 2010). This paper suggests that the weak evidence is due to a lack of studies measuring both the scope of global purchasing and the level of proficiency. Here we build on studies of how purchasing capabilities may leverage suppliers' innovativeness (e.g. Schiele, 2010; Wynstra et al., 2003). Narasimhan and Das (2001) stressed the strategic importance of purchasing and specifically showed that purchasing proficiency and practices in such activities as buyer-supplier relationship development had a clear impact on manufacturing firm performance. Cousins et al. (2006) developed a typology of purchasing roles, featuring differences in strategic involvement, status, internal integration and skills of the purchasing function. Based on British data they showed that purchasing roles were related to supplier integration and firm performance.

Supplier performance depends on how skilled the purchasing department is at forming good working relationships with suppliers (McIvor, 2009; Van Weele, 2009). Similarly, Ragatz et al. (1997) showed that practices aimed at integrating suppliers in NPD are more important for NPD success than practices aimed at selecting and 
IJOPM

35,9

1300

evaluating suppliers. Thus, we focus on proficiency in integrating suppliers. Since global purchasing is more complex than local or regional, the impact of purchasing proficiency is likely to be higher for firms purchasing globally, but the literature still lacks conclusive empirical evidence.

The previous discussion shows the need to consider both the actual supplier integration and the purchasing department's skills at integrating suppliers. We thus aim to test the following hypotheses (see Figure 2):

$H 3 a$. Supplier integration is more beneficial for firms purchasing globally, compared to firms that do not, in terms of the level of supplier product innovation.

$H 3 b$. Supplier integration is more beneficial for firms purchasing globally, compared to firms that do not, in terms of the level of TTM.

H4a. Proficiency in supplier integration is more beneficial for firms purchasing globally, compared to firms that do not, in terms of supplier product innovation.

H4b. Proficiency in supplier integration is more beneficial for firms purchasing globally, compared to firms that do not, in terms of supplier TTM.

\section{Survey and variables}

The data used in this study are from the International Purchasing Survey (IPS), an international online survey on purchasing and supply management conducted in 2009. The survey covers complete answers from 679 manufacturing firms (ISIC codes 25-30) in Europe, USA and Canada, and the data were collected by a network of partner universities. Several papers have previously been published that are based on the IPS (e.g. Kauppi et al., 2013; Luzzini et al., 2012). The questionnaire included questions on firms' purchasing strategy, practices and performance, and was mainly answered by senior purchasing managers or the equivalent.

Six-point scales were used in instances where it was important to avoid a neutral middle response (Saris and Gallhofer, 2007). In instances where avoiding a neutral middle response is not critical, e.g. when rating performance, seven-point scales were used. The responding company answered questions at both the firm level and the component category level. The respondents were asked to choose a category that was relatively homogenous in terms of products and services. The data were analysed by comparing means ( $t$-test) as well as factor and regression analysis, using SPSS software.

Figure 2.

Conceptual model, $\mathrm{H} 3$ and $H 4$

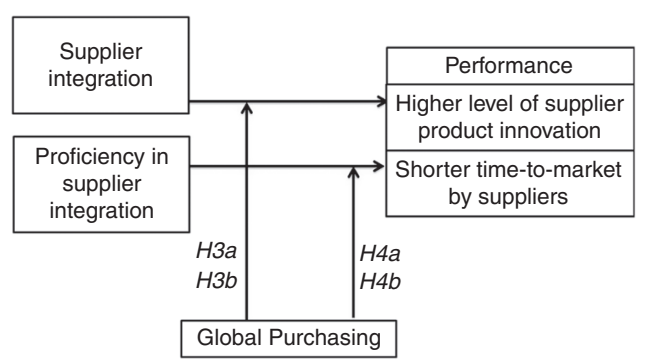




\section{Global purchasing}

This study focuses on the relative characteristics of global purchasing and distinguishes between two groups: global and regional. The geographical area of the firms' purchasing activities in combination with the respondent's home country produced the two categories, where regional means purchasing is only done within the same continent, i.e. Europe or North America. An American company purchasing from the USA and Canada and Mexico would thus be considered regional, as would a German company purchasing from, say, UK, Hungary and Italy. Any company buying from China or Australia would be considered to be engaged in global purchasing. The scope of global purchasing was measured by asking from which of the 13 predefined geographical areas the firm buys more than 10 per cent of a selected category of goods and services (Table I). The threshold of 10 per cent was selected to disregard one-of-akind contracts and focus on major purchasing patterns. A relatively low percentage is appropriate, since some innovative firms may purchase the most innovative components globally, while purchasing the majority locally in order to minimise supply risks (Mol et al., 2004). It is also possible that low-cost supplies of relatively less innovative components are only available in faraway countries, whereas the most innovative components in a category are purchased locally. The 10 per cent threshold shows that a company is indeed considering suppliers on a global scale, while the majority of actual purchasing does not need to be global, in line with Quintens et al. (2006) and Mol et al. (2004). In other words, this study measures the scope of global purchasing, but not the depth. Based on this we could define two groups, regional and global, of firms among the 679 respondents (Table I).

\section{Priorities, control variables and performance}

The question to measure priorities for purchasing was phrased "Please indicate to what extent management has emphasised the following priorities for the chosen category over the past 2 years". The priorities were measured on a six-point Likert scale, from "not at all" to "completely". Two priorities were related to innovation and thus relevant for this study (Table IV). The priorities are used for testing $H 1 a$ and $H 1 b$, but are not included in further analysis, as it is, in this context, uninteresting to analyse whether priorities correlate with performance improvement within the same area.

Home country
Eastern Europe (incl. Turkey and the Baltic states)
Western Europe
North America
Latin America
Japan, South Korea, Taiwan
Australia and New Zealand
Russia and other CIS countries
India, Pakistan, Bangladesh
China (incl. Hong Kong, Macau)
Southeast Asia (incl. Philippines, Indonesia)
Middle East
Rest of the world
Total ( $n=$ )

Regional purchasing Global purchasing Total

$\begin{array}{rrr}81 \% & 74 \% & 78 \% \\ 14 \% & 23 \% & 18 \% \\ 43 \% & 62 \% & 51 \% \\ 9 \% & 46 \% & 25 \% \\ & 11 \% & 5 \% \\ & 21 \% & 9 \% \\ & 2 \% & 1 \% \\ & 5 \% & 2 \% \\ & 15 \% & 7 \% \\ & 59 \% & 26 \% \\ & 9 \% & 4 \% \\ 382 & 6 \% & 3 \% \\ & 7 \% & 3 \%\end{array}$

Global purchasing and supplier integration

1301

\author{
$=$
}


IJOPM

35,9

1302

A typical control variable in the operations management literature is company size, usually measured as turnover. As this paper is concerned with the purchasing department, the first control variable is accordingly the turnover of the department or total purchasing spending (Table II). Since this is an international survey, some currencies needed to be converted to euros. The exchange rate used was the average exchange rate during 2010 obtained from the Central Bank of Sweden.

The most obvious contribution to innovation from suppliers occurs when the company selects suppliers that are contributing something unique and innovative. The second control variable is accordingly to what extent suppliers provide access to unique assets or resources, and was measured on a six-point scale from "extremely low" to "extremely high". By introducing the control variable, the direct effect of having innovative suppliers is removed, and the analysis can focus on how the purchasing department can leverage the innovative potential of suppliers.

As previously mentioned, two performance indicators were used: the supplier TTM for new or improved products or services and the level of innovation in products or services from suppliers. As was previously explained, these two variables may be conflicting. It is thus appropriate to use them individually, instead of combining them in one factor. The question to the respondent was phrased: "Please consider current category performance - compared to management targets - for the following objectives". Seven-point Likert scales were used, ranging from much worse than target (1) to much better than target (7). The descriptive statistics for these are displayed in Table II.

\section{Supplier integration}

Supplier integration was measured by letting the respondent indicate with what frequency a number of integration tools are used to support the purchasing activity and the relationship with supplier(s) for the chosen category, on a six-point scale ranging from "never" to "always". The tools were identified by a team of international scholars as established tools used by practitioners (see also Van Weele, 2009; Karjalainen and Salmi, 2013), and are displayed in Table III. These tools, also in line with Flynn et al. (2010), are primarily aimed at improving the flow of goods and not specifically NPD.

Not measuring supplier integration into NPD can be seen as a limitation of this study. Overcoming this limitation would probably require involving departments other than purchasing in the data collection. However, previous studies have shown that the

Table II.

Descriptive statistics for control variables, priorities, market characteristics and performance

\begin{tabular}{|c|c|c|c|c|c|c|}
\hline Variable & Scale & Min & Max & Mean & $\mathrm{SD}$ & Median \\
\hline $\begin{array}{l}\text { Control variables } \\
\text { Purchased volume (in million } € \text { ) } \\
\text { The extent to which suppliers provide access to unique } \\
\text { assets or resources }\end{array}$ & $0-\infty$ & 1 & 25,000 & 3.43 & 1.18 & 53 \\
\hline $\begin{array}{l}\text { Priorities } \\
\text { Improving time-to-market with suppliers } \\
\text { Improving introduction rates of new/improved products/ } \\
\text { services }\end{array}$ & $1-6$ & 1 & 6 & 3.43 & 1.26 & 3 \\
\hline $\begin{array}{l}\text { Performance } \\
\text { The supplier time-to-market for new or improved } \\
\text { products/services } \\
\text { The level of innovation in products/service from suppliers }\end{array}$ & $\begin{array}{l}1-7 \\
1-7\end{array}$ & $\begin{array}{l}2 \\
1\end{array}$ & $\begin{array}{l}7 \\
7\end{array}$ & $\begin{array}{l}3.89 \\
3.88\end{array}$ & $\begin{array}{l}0.93 \\
0.94\end{array}$ & $\begin{array}{l}4 \\
4\end{array}$ \\
\hline
\end{tabular}


use of tools aimed at operational integration has an impact on performance, including innovation (Flynn et al., 2010; Prajogo and Olhager, 2012). One reason for this may be because such tools afford extensive information sharing with suppliers, information that can also be utilised in the NPD process. For example, sharing production planning or inventory levels will ensure availability of components for a new product, thus supporting TTM. When the product development process speeds up, companies are also likely to be able to manage more processes, leading to a higher aggregate level of innovation (Pawar et al., 1994), although some (e.g. Cohen et al., 1996) argue that the two cannot be improved simultaneously and must be traded off.

An exploratory factor analysis was conducted for the six items for two reasons. First, we wanted to reduce their numbers to assist in further analysis. Second, the high degree of convergence between the items, as shown in Table III, would cause multicollinearity problems if treated separately. All items loaded onto a single factor with high factor loadings and a high Cronbach's $\alpha$ value, implying a high degree of construct validity (Forza, 2002). We refer to this factor as "supplier integration" from here on.

\section{Proficiency in supplier integration}

With the term proficiency in supplier integration, we refer to purchasing skills in key purchasing processes aimed at integrating suppliers (in line with Narasimhan and Das, 2001; Cousins et al., 2006). The purchasing proficiency concept builds partly on the framework of González-Benito (2007), which in turns builds on Vickery's (1991) theory of production competence. This study does not cover early purchasing activities such as finding and selecting suppliers, since those activities were presumably conducted when the firms decided to purchase regionally or globally. In contrast, we are concerned with how the established suppliers are managed. The main focus is on a logistics type of integration, since NPD process is typically beyond the scope of the purchasing department. The construct contains one item on supplier involvement in the NPD process to take into account pre-NPD activities such as providing specifications, evaluating suppliers or signing contracts related to NPD projects (see also Schiele, 2010). The other two items (Table IV) concern whether the suppliers are involved in the ordering process. Purchase orders are usually generated electronically, using an MRP or ERP system (van Weele, 2009), which requires integrating suppliers. Integrating suppliers electronically requires a high degree of proficiency, since detailed, error-free descriptions, giving the technical details of the purchased product, unit price, delivery time, etc., are required (van Weele, 2009).

Proficiency was measured by letting the respondent indicate the level of proficiency (i.e. the level of quality in executing each process) for the chosen category,

Factor

Factor loading

Share inventory-level knowledge with suppliers

0.791

Share production planning and/or demand forecast

0.755

Dedicated capacity from suppliers

Vendor- (supplier-) managed inventory

0.758

Joint planning and replenishment with suppliers

Just-in-time replenishment

0.725

0.815

0.668

Notes: Principal component analysis. Variance explained $=57$ per cent, Cronbach's $\alpha=0.85$
Global purchasing and supplier integration

1303

\section{$+$}


IJOPM

35,9

\section{4}

Table IV.

Exploratory factor analysis of proficiency in supplier integration on a six-point scale ranging from "extremely low" to "extremely high". Exploratory factor analysis was also conducted for these items, for the same reasons as the supplier integration construct. All items load onto a single factor, which assures high construct validity. The factor is used in subsequent analysis and referred to as "proficiency in supplier integration".

\section{Summary of variables}

The analysis will thus consist of two independent variables: "Supplier integration" and "Proficiency in supplier integration", and two control variables: "Purchasing volume" and "Extent to which a supplier provides access to unique assets and resources". Two dependent performance variables are used: "Supplier TTM" and the "Level of innovation sources from suppliers". Table V displays the correlation (Pearson) between all independent and dependent variables, and shows, as expected, correlations between most independent variables and dependent variables. It also shows correlations between some independent variables, which can indicate potential multicollinearity problems. However, subsequent analysis (see end of next section) shows that the variance inflation factor (VIF) is well within safe levels.

\section{Findings}

The paper presents four sets of hypotheses. The first two involve comparing the priorities and impact of global purchasing. To test for significant differences between the two groups, an independent sample $t$-test was used, as recommended by Forza (2002). The third and fourth hypotheses concern the innovation impact of supplier integration, as well as the innovation impact of proficiency in supplier integration. When a single dependent variable is presumed to be related to multiple independent variables, multiple regression analysis is appropriate (Forza, 2002). This

Item

Factor loading

Management of the order cycle

0.779

Supplier involvement in NPD

0.854

Supplier integration in order fulfilment

0.863

Notes: Principal component analysis. Variance explained $=69$ per cent, Cronbach's $\alpha=0.78$
Table V. Correlations

\begin{tabular}{llllllll}
\hline & & 1 & 2 & 3 & 4 & 5 & 6 \\
\hline $\begin{array}{l}\text { Independent } \\
\text { variables }\end{array}$ & $\begin{array}{l}\text { 1. Control variable: purchasing } \\
\text { volume (in €) }\end{array}$ & 1 & & & & & \\
& $\begin{array}{l}\text { 2. Control variable: suppliers } \\
\text { providing unique resources }\end{array}$ & 0.021 & 1 & & & \\
& $\begin{array}{l}\text { 3. Proficiency in supplier integration } \\
\text { 4. Supplier integration }\end{array}$ & $0.093^{*}$ & $0.151^{* *}$ & 1 & & & \\
& $0.147^{* *}$ & $0.174^{* *}$ & $0.260^{* *}$ & 1 & & \\
$\begin{array}{l}\text { Dependent } \\
\text { variables }\end{array}$ & $\begin{array}{l}\text { 5. Performance: supplier time-to- } \\
\text { market }\end{array}$ & $0.092^{*}$ & 0.029 & $0.219^{* * *}$ & $0.193^{* * *}$ & 1 & \\
& $\begin{array}{l}\text { 6. Performance: level of supplier } \\
\text { product innovation }\end{array}$ & 0.028 & $0.193^{* *}$ & $0.244^{* * *}$ & $0.163^{* *}$ & $0.436^{* *}$ & 1
\end{tabular}

Notes: $* p<0.05 ; * * p<0.01$ 
section will thus first present the results of the independent sample t-test and then the results of multiple regression analyses. Since there are two dependent variables and two groups of firms, a total of four regression analyses are required.

The first hypotheses concern the priorities of the purchasing department. From Table VI, we can see that there are significant differences between regional and global purchasing. Global purchasing is significantly more guided by priorities of improving TTM and rates of new products than those purchased regionally, thus supporting $H 1 a$ and $H 1 b$.

The second set of hypotheses concerns the outcome of regional and global purchasing, in terms of product innovation. The results show that there are no significant differences between the groups. Supplier TTM and the level of supplier product innovation appear to be unrelated to where the suppliers are located, thus providing no support for $\mathrm{H} 2 a$ and $H 2 b$.

The third and fourth sets of hypotheses concern the impact of supplier integration and the impact of proficiency in supplier integration, and whether they differ between firms purchasing globally and firms purchasing locally. The results in Tables VII and VIII show that supplier integration is strongly associated with shorter supplier TTM but not with level of supplier product innovation, and only for firms purchasing globally. We thus find support for $H 3 b$, but not for $H 3 a$. Integrating global suppliers is thus

\begin{tabular}{|c|c|c|c|}
\hline & $\begin{array}{l}\text { Regional } \\
\text { purchasing }\end{array}$ & $\begin{array}{c}\text { Global } \\
\text { purchasing }\end{array}$ & Significance \\
\hline Purchasing volume (mean, in $\mathrm{M€)})^{\mathrm{a}}$ & 392 & 893 & 0.05 \\
\hline Median (in M€) & 52 & 55 & 0.91 \\
\hline $\begin{array}{l}\text { Suppliers of this category provide access to unique } \\
\text { assets }\end{array}$ & 3.41 & 3.45 & 0.63 \\
\hline $\begin{array}{l}\text { Priorities } \\
\text { Improving introduction rates of new/improved } \\
\text { products/services }\end{array}$ & 3.05 & 3.34 & 0.00 \\
\hline Improving time-to-market with suppliers & 3.26 & 3.63 & 0.00 \\
\hline Innovation outcome & & & \\
\hline The level of supplier product innovation & 3.90 & 3.85 & 0.48 \\
\hline Supplier time-to-market & 3.90 & 3.89 & 0.89 \\
\hline
\end{tabular}

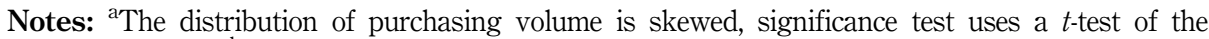
logarithmic value; ${ }^{\mathrm{b}}$ Independent sample median test
Global purchasing and supplier integration

1305
Table VI. Character and competitive priorities of the purchased category (mean values)

\begin{tabular}{lcc}
\hline Dependent: level of supplier product innovation & Regional purchasing & Global purchasing \\
\hline Purchasing spend (log) & -0.07 & -0.06 \\
Suppliers providing unique resources & 0.05 & $0.23^{* *}$ \\
Supplier integration & 0.06 & 0.04 \\
Proficiency in supplier integration & 0.11 & $0.29^{* *}$ \\
$R^{2}$ & 0.03 & 0.18 \\
Adjusted $R^{2}$ & 0.01 & 0.16 \\
$F$-value & 1.60 & $9.78^{* *}$
\end{tabular}

Notes: Standardised $\beta$ coefficients $(\beta)$ for independent variables. ${ }^{*} p<0.05 ; * * p<0.01$

Table VII.

The impact of purchasing proficiency and supplier integration 
IJOPM

35,9

1306

important to ensure short TTM, but is not enough for ensuring a high level of supplier innovation. Supplier integration is not very important for firms purchasing regionally, at least not in terms of these two performance indicators.

The results also show that proficiency in supplier integration is strongly associated with the level of supplier product innovation, but only for firms purchasing globally, thus supporting $H 4 a$. Moreover, proficiency in supplier integration is also associated with shorter supplier TTM for all firms, providing no support for $H 4 b$.

Of the control variables, only one significant effect was detected: suppliers proving unique resources is strongly associated with level of supplier product innovation for firms purchasing globally, which is indeed in line with the reviewed literature. Purchasing volume is not related to innovation performance in any way.

Both models for firms purchasing globally display satisfactory explanatory power ( $R^{2}$ and adjusted $R^{2}$ ), and the $F$-value is statistically significant. For the regional sourcing group, only the model with dependent variable supplier TTM is statistically significant, although the $R^{2}$ values are rather low. The VIF is consistently below 1.3, indicating no multicollinearity problems. Ten is usually considered the threshold for potential multicollinearity problems (Cohen et al., 2003). Thus, the regression models for the global purchasing group provide valuable insight into factors contributing to supplier innovation performance, whereas the models are insufficient for explaining what drives supplier innovation performance for firms purchasing regionally. A normal probability plot showed that, for the global purchasing group, the standardised residuals behave randomly, which suggests that the data fit the model well (NIST/ SEMATECH e-Handbook of Statistical Methods, 2014). For the regional purchasing groups, the residuals do not behave randomly, which strengthens our conviction that other variables are needed to explain supplier innovation for this group.

\section{Discussion}

Previous studies have identified the search for innovation as a key driver of global purchasing (e.g. Mol et al., 2004; Luzzini and Ronchi, 2011). The results of this study provide support for this view: firms purchasing globally are significantly more likely to cite the search for innovation as a priority for purchasing. Moreover, firms purchasing globally are also significantly more likely to prioritise reducing TTM, probably because they are aware of the negative effects on TTM that a long distance may have. Firms may expect that new ways of working, for example common tools like e-mail, web meetings or ERP systems, have made global NPD more manageable (Durmuşoğlu and Barczak, 2011; Olson et al., 2013) and able to mitigate the negative effect of geographical distance observed by previous studies (Allocca and Kessler, 2006;

\begin{tabular}{lcc}
\hline Dependent: supplier time-to-market & Regional purchasing & Global purchasing \\
\hline Purchasing spend (log) & 0.05 & 0.06 \\
Suppliers providing unique resources & 0.01 & -0.06 \\
Supplier integration & 0.05 & $0.28^{* *}$ \\
Proficiency in supplier integration & $0.19^{* *}$ & $0.15^{*}$ \\
$R^{2}$ & 0.05 & 0.13 \\
Adjusted $R^{2}$ & 0.03 & 0.11 \\
$F$-value & $2.66^{*}$ & $6.67^{* *}$
\end{tabular}

Table VIII.

The impact of purchasing proficiency and supplier integration

Notes: Standardised $\beta$ coefficients $(\beta)$ for independent variables. $* p<0.05 ; * * p<0.01$ 
Bengtsson and Berggren, 2008). Another reason may be that firms expect that competent suppliers, which are more likely to be found in a global search (Kotabe et al., 2008; Mol et al., 2004), will reduce TTM by more than the greater geographical distance would increase TTM.

There has been a rather frequent concern that geographical distance has a negative effect on innovation performance (Dankbaar, 2007; Liu et al., 2013). Previous studies (e.g. Allocca and Kessler, 2006; Bengtsson and Berggren, 2008), showed that global purchasing can have a negative impact on TTM, whereas the effects on the level of supplier product innovation are less clear in the literature. This study finds no such negative effects: firms purchasing globally do not perform better or worse than firms purchasing locally in terms of product innovation and TTM from suppliers. Keep in mind that the threshold at which we considered firms to be purchasing globally was if more than 10 per cent of a category is purchased globally, in line with Mol et al. (2004) and Quintens et al. (2006). This study confirms that actual global purchasing is less relevant for innovation performance than how the purchasing is managed, which further highlights the relevance of $H 3$ and $H 4$, which focus on the impact of supplier integration.

Although this study showed that global purchasing does not influence the innovation outcome directly, the findings did show that for firms purchasing globally there is a strong link between supplier integration and supplier product innovation, as well as between proficiency in supplier integration and supplier product innovation. In other words, performance depends on how well they integrate their suppliers and what supplier integration tools they use. That high proficiency in purchasing results in a higher level of innovation from suppliers has been established in the literature (e.g. Wynstra et al., 2003; Schiele, 2010), but that companies purchasing locally fail to reap the benefits is more surprising. That supplier integration is associated with shorter TTM has also been well documented by previous empirical studies (Lau et al., 2010; Schiele, 2010; Perols et al., 2013). The surprise is again that this association is only valid for firms purchasing globally.

Four interrelated explanations have been identified. First, whereas IT tools may be essential for managing global NPD, there are alternatives, such as meeting in person, when suppliers are located closer. Thus, the difference between using IT tools and not using them is likely to be higher if the distance is greater, thereby mitigating the hypothesised negative impact of distance. Second, global purchasing is a relatively new phenomenon for many firms and requires particularly high proficiency in supplier integration and extensive supplier integration to prevent a negative impact on innovation. Local suppliers that the customer firms already know require little formal integration. This explanation is in line with previous studies showing that supplier integration is particularly important when outsourcing (e.g. Bengtsson et al., 2009). In this view, supplier integration is a prerequisite for global purchasing, since it allows customers to get to know new suppliers in a systematic way. Third, since firms that source regionally are likely to have a longer history in dealing with their suppliers, their suppliers are directly involved with other departments such as R\&D, thus bypassing the purchasing department. This would imply that firms that plan to source more globally would be wise to move resources to the purchasing department from other departments, whereas firms purchasing regionally can afford to have a more lightly staffed purchasing department. The fourth and final identified explanation is that supplier integration is only effective if suppliers are capable, and there simply are not enough capable suppliers locally (Kotabe and Mol, 2009). However, this explanation is unlikely to be true, since there is no difference between the two groups when it comes to suppliers providing unique assets or resources. It is possible, but somewhat unlikely, that local suppliers are unique, but not in the areas required for innovation. 
IJOPM

35,9

1308

\section{Conclusions}

Although the literature suggested that geographical distance has a negative effect on innovation, this study finds no difference in the level of supplier product innovation or supplier TTM between firms that purchase globally and those that do not, even though firms purchasing globally are significantly more likely to declare product innovation a priority for their purchasing departments. A conclusion to draw is that just purchasing globally does not automatically translate into higher, or lower, innovation. However, companies that source globally are significantly better at translating supplier integration and proficiency in supplier integration into higher levels of product innovation actually sourced from suppliers, as well as shorter TTM. These findings are not related to purchasing volume, meaning smaller firms have the same potential for leveraging their purchasing department's proficiency and the use of supplier integration when purchasing globally as larger firms. It can therefore be concluded that global purchasing is beneficial for product innovation, provided that the firms possess adequate proficiency in supplier integration and apply appropriate supplier integration tools.

This paper contributes to the discussion of potential advantages and disadvantages of global purchasing. First, the paper provides an explanation for the ambiguous results of previous research (e.g. Allocca and Kessler, 2006; Steinle and Schiele, 2008; Saranga and Moser, 2010). Product innovation does not depend on whether firms are purchasing globally or not, it depends on how they purchase. This paper has showed that when purchasing globally, the role of the purchasing department becomes crucial for product innovation. The proficiency and activities of the purchasing department largely determine the success, in terms of supplier product innovation, of global purchasing.

The implication is that when companies purchase globally, they must have a highly developed purchasing department in order to sustain a high level of innovation. For firms purchasing only regionally, the role of the purchasing department is diminished, at least in terms of contributing to innovation. Contrary to our expectations, global purchasing does not need to have a negative impact on TTM either, with the same caveats: that the purchasing department possess enough proficiency in supplier integration and that they indeed integrate their suppliers.

This paper has identified several key factors for achieving higher levels of supplier product innovation and shorter TTM from suppliers when purchasing globally. The impact is very weak or nonexistent for firms purchasing regionally. As mentioned in the discussion, factors other than those included in this paper play a bigger role in leveraging supplier product innovation for these firms. Exploring this issue is an area ripe for further research.

\section{References}

Allocca, M.A. and Kessler, E.H. (2006), "Innovation speed in small and medium-sized enterprises", Creativity and Innovation Management, Vol. 15 No. 3, pp. 279-295.

Bengtsson, L. and Berggren, C. (2008), “The integrator's new advantage - reassessing outsourcing and production competence in a global telecom firm", European Management Journal, Vol. 26 No. 5, pp. 314-324.

Bengtsson, L., von Haartman, R. and Dabhilkar, M. (2009), "Low-cost versus innovation: contrasting outsourcing and integration strategies in manufacturing", Creativity and Innovation Management, Vol. 18 No. 1, pp. 35-47.

Brusoni, S., Prencipe, A. and Pavitt, K. (2001), "Knowledge specialization, organizational coupling and the boundaries of the firm: why do firms know more than they make?", Administrative Science Quarterly, Vol. 46 No. 4, pp. 597-621. 
Chiang, C.-Y., Kocabasoglu-Hillmer, C. and Suresh, N. (2012), "An empirical investigation of the impact of strategic sourcing and flexibility on firm's supply chain agility", International Journal of Operations \& Production Management, Vol. 32 No. 1, pp. 49-78.

Chiesa, V., Manzini, R. and Tecilla, F. (2000), "Selecting sourcing strategies for technological innovation: an empirical investigation", International Journal of Operations \& Production Management, Vol. 20 No. 9, pp. 1017-1037.

Cohen, J., Cohen, P., West, S. and Aiken, L. (2003), Applied Multiple Regression/Correlation: Analysis for the Behavioral Sciences, 3rd ed., Erlbaum, Mahwah, NJ.

Cohen, M.A., Eliasberg, J. and Ho, T.-H. (1996), "New product development: the performance and time-to-market tradeoff”, Management Science, Vol. 42 No. 2, pp. 173-186.

Contractor, F.J., Kumar, V., Kundu, S.K. and Pedersen, T. (2010), "Reconceptualizing the firm in a world of outsourcing and offshoring: the organizational and geographical relocation of highvalue company functions", Journal of Management Studies, Vol. 47 No. 8, pp. 1417-1433.

Cousins, P.D., Lawson, B. and Squire, B. (2006), "An empirical taxonomy of purchasing functions", International Journal of Operations \& Production Management, Vol. 26 No. 7, pp. 775-794.

Dankbaar, B. (2007), "Global sourcing and innovation:the consequences of losing both organizational and geographical proximity", European Planning Studies, Vol. 15 No. 2, pp. 271-288.

Demeter, K. (2013), "Time-based competition - the aspect of partner proximity", Decision Support Systems, Vol. 54 No. 4, pp. 1533-1540.

Durmuşoğlu, S.S. and Barczak, G. (2011), "The use of information technology tools in new product development phases: analysis of effects on new product innovativeness, quality, and market performance", Industrial Marketing Management, Vol. 40 No. 2, pp. 321-330.

Fawcett, S.E., Magnan, G.M. and McCarter, M.W. (2010), "Benefits, barriers and bridges to effective supply chain management", Supply Chain Management: An International Journal, Vol. 13 No. 1, pp. 35-48.

Flynn, B.B., Huo, B. and Zhao, X. (2010), “The impact of supply chain integration on performance: a contingency and configuration approach", Journal of Operations Management, Vol. 28 No. 1 , pp. 58-71.

Forza, C. (2002), "Survey research in operations management: a process-based perspective", International Journal of Operations \& Production Management, Vol. 22 No. 2, pp. 152-194.

Golini, R. and Kalchschmidt, M. (2011), "Moderating the impact of global sourcing on inventories through supply chain management", International Journal of Production Economics, Vol. 133 No. 1, pp. 86-94.

Gonzalez-Benito, J. (2007), "A theory of purchasing's contribution to business performance", Journal of Operations Management, Vol. 25 No. 4, pp. 901-917.

Henke, J.W. Jr and Zhang, C. (2010), "Increasing supplier-driven innovation", MIT Sloan Management Review, Vol. 5 No. 2, pp. 41-46.

Holweg, M., Reichhart, A. and Hong, W. (2011), "On risk and cost in global sourcing", International Journal of Production Economics, Vol. 131 No. 1, pp. 333-341.

Huber, F. (2012), "Do clusters really matter for innovation practices in information technology? Questioning the significance of technological knowledge spillovers", Journal of Economic Geography, Vol. 12 No. 1, pp. 107-126.

Karjalainen, K. and Salmi, A. (2013), "Continental differences in purchasing strategies and tools", International Business Review, Vol. 22 No. 1, pp. 112-125.

Karlsson, C. and Åhlström, P. (1999), "Technological level and product development cycle time", Journal of Product Innovation Management, Vol. 16 No. 4, pp. 352-362. 
IJOPM

35,9

1310

Kauppi, K., Brandon-Jones, A., Ronchi, S. and van Raaij, E.M. (2013), "Tools without skills: exploring the moderating effect of absorptive capacity on the relationship between e-purchasing tools and category performance", International Journal of Operations \& Production Management, Vol. 33 No. 7, pp. 828-857.

Kleinschmidt, E.J., De Brentani, U. and Salomo, S. (2007), "Performance of global new product development programs: a resource-based view", Journal of Product Innovation Management, Vol. 24 No. 5, pp. 419-441.

Kotabe, M. and Mol, M.J. (2009), "Outsourcing and financial performance: a negative curvilinear effect”, Journal of Purchasing and Supply Management, Vol. 15 No. 4, pp. 205-213.

Kotabe, M., Murray, J.Y. and Mol, M.J. (2008), "Global sourcing strategy and performance: a 'fit' versus 'balance' perspective”, Research in Global Strategic Management, Vol. 14 No. 14, pp. 259-278.

Kraljic, P. (1983), "Purchasing must become supply management", Harvard Business Review, Vol. 61 No. 5, pp. 109-117.

Lau, A.K.W., Tang, E. and Yam, R.C.M. (2010), "Effects of supplier and customer integration on product innovation and performance: empirical evidence in Hong Kong manufacturers", Journal of Product Innovation Management, Vol. 27 No. 5, pp. 761-777.

Liu, J., Chaminade, C. and Asheim, B. (2013), “The geography and structure of global innovation networks: a knowledge base perspective”, European Planning Studies, Vol. 21 No. 9, pp. 1-18.

Luzzini, D. and Ronchi, S. (2011), "Organizing the purchasing department for innovation", Operations Management Research, Vol. 4 Nos 1/2, pp. 14-27.

Luzzini, D., Caniato, F., Ronchi, S. and Spina, G. (2012), "A transaction costs approach to purchasing portfolio management", International Journal of Operations \& Production Management, Vol. 32 No. 9, pp. 1015-1042.

McIvor, R. (2009), "How the transaction cost and resource-based theories of the firm inform outsourcing evaluation”, Journal of Operation Management, Vol. 27 No. 1, pp. 45-63.

Mol, J., Pauwels, P., Matthyssens, P. and Quintens, L. (2004), “A technological contingency perspective on the depth and scope of international outsourcing", Journal of International Management, Vol. 10 No. 2, pp. 287-305.

Mol, M.J., van Tulder, R.J.M. and Beije, P.R. (2005), “Antecedents and performance consequences of international outsourcing", International Business Review, Vol. 14 No. 5, pp. 599-617.

Monczka, R., Trent, R. and Handfield, R. (2005), Purchasing and Supply Chain Management, Southwestern/Thomson Learning, Cincinnati, $\mathrm{OH}$.

Mudambi, R. (2008), "Location, control and innovation in knowledge-intensive industries", Journal of Economic Geography, Vol. 8 No. 5, pp. 699-725.

Murray, J.Y. (2001), "Strategic alliance-based global sourcing strategy for competitive advantage: a conceptual framework and research propositions", Journal of International Marketing, Vol. 9 No. 4, pp. 30-58.

Narasimhan, R. and Das, A. (2001), "The impact of purchasing integration and practices on manufacturing performance", Journal of Operations Management, Vol. 19 No. 5, pp. 563-609.

Narasimhan, R. and Nair, A. (2005), "The antecedent role of quality, information sharing and supply chain proximity on strategic alliance formation and performance", International Journal of Production Economics, Vol. 96 No. 3, pp. 301-313.

NIST/SEMATECH e-Handbook of Statistical Methods (2014), available at: www.itl.nist.gov/ div898/handbook/ (accessed 22 May 2014).

Olson, D.L., Chae, B.K. and Sheu, C. (2013), "Relative impact of different ERP forms on manufacturing organisations: an exploratory analysis of a global manufacturing survey", International Journal of Production Research, Vol. 51 No. 5, pp. 1520-1534. 
Pawar, K.S., Menon, U. and Riedel, J.C.K.H. (1994), “Time to market”, Integrated Manufacturing Systems, Vol. 5 No. 1, pp. 14-22.

Perols, J., Zimmermann, C. and Kortmann, S. (2013), “On the relationship between supplier integration and time-to-market”, Journal of Operations Management, Vol. 31 No. 3, pp. 153-167.

Prajogo, D. and Olhager, J. (2012), "Supply chain integration and performance: the effects of longterm relationships, information technology and sharing, and logistics integration", International Journal of Production Economics, Vol. 135 No. 1, pp. 514-522.

Global purchasing and supplier integration

1311

Quintens, L., Pauwels, P. and Matthyssens, P. (2006), "Global purchasing strategy: conceptualization and measurement”, Industrial Marketing Management, Vol. 35 No. 7, pp. 881-891.

Ragatz, G.L., Handfield, R.B. and Scannell, T.V. (1997), "Success factors for integrating suppliers into new product development", Journal of Product Innovation Management, Vol. 14 No. 3, pp. 190-202.

Saranga, H. and Moser, R. (2010), "Performance evaluation of purchasing and supply management using value chain DEA approach", European Journal of Operational Research, Vol. 207 No. 1, pp. 197-205.

Saris, W.E. and Gallhofer, I. (2007), Design, Evaluation and Analysis of Questionnaires for Survey Research, Wiley Interscience, Hoboken, NJ.

Schiele, H. (2010), "Early supplier integration: the dual role of purchasing in new product development”, R\&D Management, Vol. 40 No. 2, pp. 138-153.

Schiele, H., Horn, P. and Vos, B. (2011), "Estimating cost-saving potential from international sourcing and other sourcing levers: relative importance and trade-offs", International Journal of Physical Distribution \& Logistics Management, Vol. 41 No. 3, pp. 315-336.

Steinle, C. and Schiele, H. (2008), "Limits to global sourcing?", Journal of Purchasing and Supply Management, Vol. 14 No. 1, pp. 3-14.

Trent, R.J. and Monczka, R.M. (2003), "International purchasing and global sourcing - what are the differences?”, Journal of Supply Chain Management, Vol. 39 No. 4, pp. 26-36.

Ulrich, K.T. and Ellison, D.J. (2005), "Beyond make-buy: internalization and integration of design and production", Production and Operations Management, Vol. 14 No. 3, pp. 315-330.

van Weele, A.J. (2009), Purchasing and Supply Chain Management, 5th ed., Cengage Learning, London.

Vickery, S.K. (1991), "A theory of production competence revisited”, Decision Sciences, Vol. 22 No. 3, pp. 635-643.

Wynstra, F., Weggeman, M. and van Weele, A. (2003), "Exploring purchasing integration in product development”, Industrial Marketing Management, Vol. 32 No. 1, pp. 69-83.

\begin{abstract}
About the authors
Dr Robin von Haartman is an Assistant Professor in Logistics and Supply Chain Management at the University of Gävle. He holds a PhD in Industrial Management and Work Science from The Royal Institute of Technology (KTH). Previous and current research focus on issues such s manufacturing strategies, manufacturing outsourcing, global sourcing and supply chain design. Dr Robin von Haartman is the corresponding author and can be contacted at: Robin.vonHaartman@hig.se

Lars Bengtsson is a Professor in Innovation Management at the University of Gävle, Sweden, Associate Professor at the KTH in Stockholm and a member of KITE research group at the Linköping University. He currently leads research focusing on innovation management, knowledge integration, manufacturing strategies and outsourcing in industrial firms.
\end{abstract}

For instructions on how to order reprints of this article, please visit our website:

www.emeraldgrouppublishing.com/licensing/reprints.htm

Or contact us for further details: permissions@emeraldinsight.com 